\title{
CONCEPT-MAPPING AS A TEACHING METHOD TO FACILITATE CRITICAL THINKING IN NURSING EDUCATION: A REVIEW OF THE LITERATURE
}

Author:

Mary M. Chabeli ${ }^{1}$

\author{
Affiliation: \\ ${ }^{1}$ Department of \\ Nursing, University of \\ Johannesburg, \\ South Africa
}

\section{Correspondence to:}

Mary Chabeli

email:

maryc@uj.ac.za

\section{Postal address:}

PO Box 524, Auckland

Park 2006, South Africa

\section{Keywords:}

Critical thinking; conceptmapping; facilitation; teaching methods; nursing education

\section{Dates:}

Received: 02 Apr. 2009

Accepted: 24 Feb. 2010

Published: 20 Aug. 2010

How to cite this article:

Chabeli, M., 2010,

'Concept-mapping as

a teaching method to

facilitate critical thinking

in nursing education: A

review of the literature',

Health SA Gesondheid 15(1),

Art. \#432, 7 pages. DOI:

10.4102/hsag.v15i1.432

This article is available at:

http:/ / www.hsag.co.za
(C) 2010. The Authors.

Licensee: OpenJournals Publishing. This work

is licensed under the

Creative Commons

Attribution License.

\section{ABSTRACT}

Nursing students are exposed to a vast amount of information and reading material that is very specific, technical, and new to the students. Unless nurse educators provide a learning environment that promotes understanding through interaction, students might only commit unassimilated information to their short-term memory through rote learning, and no meaningful learning will occur. Nursing students must be able to link learned facts, concepts and principles with new knowledge in order to make sound rational decisions in practice (All \& Havens 1997:1210, 1213).

The aim of this paper is to describe the utilisation of concept-mapping as a teaching method to facilitate critical thinking by students in nursing education. The description of the utilisation of concept-mapping is done from the theoretical framework of concept-mapping and critical thinking to provide the epistemological basis for concept-mapping (Facione 1990:6,13). Based on the exploration and description of the theoretical frameworks, four steps to facilitate critical thinking were formulated through concept-mapping on the basis of the educational process: the identification, interactive constructing process, formulation and evaluation steps.

It is concluded that the utilisation of these steps will assist nurse educators to implement conceptmapping as a teaching method to facilitate critical thinking by student nurses in nursing education. Recommendations are made.

\section{OPSOMMING}

Verpleegkundestudente word blootgestel aan 'n geweldige hoeveelheid inligting en leesmateriaal wat baie spesifiek, tegnies en nuut is vir die studente. Tensy verpleegkundeopvoeders ' $n$ leeromgewing kan voorsien wat deur interaksie die bevordering van begrip bewerkstellig, kan studente inligting deur papegaaiwerk in hul korttermyngeheue stoor, eerder as om dit te assimileer - geen betekenisvolle leer sal dus plaasvind nie. Verpleegkundestudente moet die vermoë hê om die verband tussen aangeleerde feite, konsepte en beginsels en nuwe kennis te lê sodat hulle in die praktyk rasionale besluite kan maak (All \& Havens 1997:1210, 1213).

Hierdie artikel het ten doel om die aanwending van konsepkartering as 'n onderrigstrategie te beskryf, ten einde die kritiese denke van leerders in die verpleegkunde te fasiliteer. Die beskrywing van die aanwending van konsepkartering word vanuit die teoretiese raamwerke van konsepkartering en kritiese denke gedoen om die epistemologiese grondslag vir konsepkartering te voorsien (Facione 1990:6, 13). Gegrond op die verkenning en beskrywing van die teoretiese raamwerke, word vier fases vir die fasilitering van kritiese denke geformuleer deur middel van konsepkartering. Hierdie verkenning en beskrywing is gebaseer op die onderwysproses: die identifiseringsfase, die interaktiewe konstrueringsproses, die formuleringsfase en evalueringsfase.

Die gevolgtrekking word gemaak dat die aanwending van hierdie fases verpleegopvoeders behulpsaam sal wees in die implementering van konsepkartering as 'n onderrigmetode om kritiese denke by leerling verpleërs te fasiliteer in verpleegkunde-onderwys. Aanbevelings word gemaak.

\section{INTRODUCTION}

Facilitating critical thinking remains a challenge faced by both nurse educators and student nurses, especially in the multi-modal and learner-centred approach to learning. The facilitation of critical thinking in teaching and learning requires a willingness and commitment to engage in the utilisation of the core cognitive critical thinking skills and the related affective dispositions. Infusing critical thinking skills into didactic activities requires the construction and reconstruction of meanings by students through actively seeking to integrate new knowledge with knowledge already existing in their cognitive structure. Cognitive structure is a term used by Ausubel (in Mellish, Brink \& Paton 1998:28) to describe a person's existing knowledge of a particular subject and how well organised and clear that knowledge is. Concept-mapping has been identified as a stimulating learning method to facilitate critical thinking by encouraging students to connect new knowledge to their prior learning, and to give students an opportunity to gain further, wide and varied knowledge of a number of concepts in a short period (Akinsanya \& Williams 2004:41).

If students can link new information to their existing conceptual framework, they can construct new, meaningful interconnections so that their existing conceptions are transformed, enriched or revised and conceptual change occurs. Therefore, existing conceptions are transformed during knowledge construction, that is, construction of understanding (Gravett 2001:19). Interaction, collaboration, cooperation, dialogue and discourse are key concepts in facilitating understanding of educational activities. Novak (2007:1) asserts that collaborative group learning facilitates meaningful learning and new knowledge construction. Worldwide, the power and value of knowledge and new knowledge 
production are acknowledged. The interactive approaches compel the educational institutions to revisit their approaches to teaching, learning and assessment if they are to be dynamic, lively, spirited and responsible pathfinders for societies and nations (Rensburg 2007:22). A pathfinder is defined as one who discovers a new course or way, especially through or into unexplored regions (Rensburg 2007:4). Teaching and learning approaches should seek to develop the student's free and rigorous intellectual inquiry and critical thinking skills. Concept-mapping has proved to be one of the most challenging learning experiences that facilitate critical and creative thinking skills (Akinsanya \& Williams 2004:41)

The outcomes-based education (OBE) approach to teaching and learning, the six critical cross-field outcomes and the South African Nursing Council's philosophy about educational programmes all require students to make rational decisions and solve problems in practice by using innovative teaching and assessment methods. However, nurse educators still use various methods of teaching in a robotic manner (Mellish et al. 1998:103). This traditional education practice encourages rote learning, passivity, rigidity, non-reflectiveness and uncritical thinking in students (Chabeli 2006:79). The emphasis is on what the nurse educator hopes to achieve and not on the outcomes - what the student is able to do, analyse, synthesise and apply successfully at the end of the instruction (Van der Horst \& McDonald 1997:5, $21,27)$. OBE is a hands-on learning approach that encourages students to be actively engaged in the construction of their own learning and to demonstrate critical and creative thinking through interactive dialogue.

Worldwide, educators are urged to engage in scientific research to determine the validity and value of teaching and assessment methods and to lay down guidelines for the educators who have to utilise the methods in the classroom. There is a growing body of research on how to improve classroom instruction (Woolfolk 1990:ix). Fraser, Loubser and Van Rooy (1993:77) argue that teaching should have a scientific character and that the science of teaching practice by the educator should succeed in revealing the subject content to the student. Nurse educators should be well acquainted with the nature and structure of the science that they practice so that the full force thereof can be utilised during teaching. The varied teaching methods used for instruction, be it in the classroom or in a clinical setting, should also have a scientific character (improved through research). It is therefore important that nurse educators play their role as researchers to investigate the didactic validity of teaching and assessment methods on a continuous basis and to lay down guidelines to improve the practice of educators and promote critical thinking by student nurses.

It is to achieve the aforementioned goals that forms the focus of this paper - exploring concept-mapping as a teaching method to facilitate critical thinking. The steps involved in conceptmapping will also be described to assist nurse educators to utilise the method effectively.

\section{Assumptions}

The author believes that concept-mapping is an integral teaching method to facilitate critical thinking. Concept-mapping encourages meaningful understanding by helping students to organise and connect the information they already know about a subject with the new knowledge. The understanding is brought about by the student's ability to meaningfully connect, link and integrate new ideas, thoughts, concepts and statements to their existing body of knowledge. The students are able to link and cross-link the concepts and describe their relationship. They then see the 'bigger picture' of the phenomenon. Through conceptmapping the nurse educator can determine the intellectual growth of students and also diagnose their misunderstanding through misdirected links or wrong connections. The student's conceptual knowledge is illustrated well through conceptmapping.

\section{THEORETICAL FRAMEWORK}

Relevant literature was drawn on in order to provide a definition of concept-mapping and a theoretical framework and epistemological foundation for concept-mapping as a teaching method. A description is then offered of the process of utilising concept-mapping in steps to assist nurse educators to facilitate critical thinking by student nurses.

\section{Concept-mapping as a teaching method}

According to All and Havens (1997:1210), concepts are graphical or pictorial arrangements that deal with a specific subject matter. They are useful tools in representing the structure of knowledge in a form that is psychologically compatible with the way in which human beings construct meaning. Mouton (1996:181) defines a concept as the most elementary symbolic construction by means of which people classify or categorise reality or make sense of and attribute meaning to their world. Paul (1993:109) defines a concept as a generalised idea or thought of a thing or of a class of things. Concepts play an integral part in language construction and, according to Vygotsky (1978:89), language is an internal, mental function through which we develop intellectually, because language provides the tool for expressing ideas and developing an inquiring mind. No thinking can occur in a vacuum (Dewey 1933:99).

A concept is a perceived regularity in events or objects, or records of events or objects, designated by a label. Concept maps are graphical tools for organising and representing knowledge in networks of concepts and linking statements about a problem or subject (Novak \& Canas 2006:1). Concept maps include concepts, usually enclosed in circles or boxes of some type and relationships between concepts or propositions, indicated by a connecting line and linking words between concepts. Propositions are statements about some object or event that contain two or more concepts connected by linking words or phrases to form a meaningful statement. Mouton (1996:190) defines statements as sentences that contain demonstrable, testable claims about the world. Such statements make epistemic or knowledge claims.

Concept-mapping as a teaching method to promote critical thinking is based on the theoretical foundation laid down by educational psychologists (Ausubel 1963; Ausubel, Novak \& Hanesian 1978). The fundamental idea is to determine how learning occurs and how thinking develops. Educational psychology is a course taken as part of educators' professional preparation for understanding teaching and learning. Educational psychology stresses productive thinking as a component of the all-round development of personality and the nature of abilities to learn. According to Tikhomirov (1988:268), productive thinking is viewed as the basis for the student's ability to learn, as the capacity for acquiring new knowledge and as the intellectual or mental ability to be educated. Some of the indicators of the mental ability to learn are independent decision making and problem-solving, the level of the student's ability to generalise, the scope of application of new knowledge, the rate and ease of the assimilation of new knowledge and how quickly headway is made in learning (Tikhomirov 1988:268).

It is argued that students are unique individual beings whose way of learning may be unique to them, and that educators should take these differences into account when they plan and execute their teaching methods (Fraser et al. 1993:64). However, a major trend in improving educational practices is enhancing the 'share' of knowledge as a basis for shaping critical thinking (Tikhomirov 1988:268). Using teaching methods that encourage interaction, dialogue, discourse and collaborative learning (Fraser et al. 1993:52; Gravett 2001:47; Mellish et al. 1998:33) is integral to the facilitation of critical thinking by students and concept-mapping is one such teaching method. 
No teaching strategy can be planned and executed effectively if the educator does not know how learning takes place and which factors can contribute to meaningful and optimal learning (Fraser et al. 1993:77). The main principle of the cognitive psychologist Ausubel's assimilation theory is that, for meaningful learning to occur, the student must incorporate new information into an existing cognitive structure. The substantive and organisational properties of the cognitive structure have a crucial influence on both the accuracy and clarity of the emerging new meanings, and on a person's immediate and long-term ability to retrieve information. The better the student's knowledge is organised, structured or connected, the more effectively it can be accessed when needed. The more concepts the student acquires, the more interconnections and cross-links the student can make between them. This results in the student having a richly connected and finely integrated conceptual framework for meaningful learning (Gravett 2001:19).

In order to achieve meaningful learning, Ausubel (in Mellish et al. 1998:27) asserts that the student must have an appropriate learning set or intention, which means that the student must consciously decide to learn the material meaningfully, rather than in a rote fashion. Students should take responsibility for their own learning. They should choose to learn meaningfully and have the emotional commitment to integrate new meanings with existing, relevant knowledge, rather than simply memorising concept definitions or propositional statements. Paul (1993:472) concurs with Ausubel by stating that, for critical thinking to occur, students should have 'intellectual responsibility', in terms of which they feel strongly obliged to achieve a high degree of precision and accuracy in their reasoning and are deeply committed to gathering complete, relevant and adequate evidence. Learning set or intention can be equated with learner readiness, which, according to Knowles (1980:51), depends on what the students feel they need to know or do, that is, on things that are necessary for them to know in order to advance from one phase of intellectual development to the next. Learner readiness, according to Thompson and Jolley (1997:129), is an attitude of mind that encompasses motivation and capability for the manifestation of self-directed learning behaviour.

Ausubel (in Mellish et al. 1998:27) states that, for learning to occur, the learning material must be conceptually clear and presented with language and examples relatable to the student's existing knowledge framework so as to enrich the student's existing conceptions and ideas. Conceptual clarity leads to indicators that may assist the student in altering his or her existing knowledge structure in the light of the new information (Mouton 1996:118). The student should construct new meanings and new ways of thinking (Gravett 2001:18). The learning task must have a logical meaning that can be related to the student's own cognitive structure. The student's cognitive structure must contain relevant ideas to which the new material can be anchored or connected. Concepts are powerful building blocks for the meaningful construction of knowledge.

Cognitive theories emphasise the human mind as an active and individual processor of information. They focus on the human mind's active attempt to make sense of the whole. Kohler (in Quinn 2000:84), from a Gestalt school of psychology, refers to the wholeness approach to learning as insightful learning, in which the student's perception of a situation or problem undergoes a restructuring and the student sees the aspects of the situation in a new relationship to one another. This new relationship forms a unified whole or Gestalt that is meaningful to the student, who is then said to have insight into the problem or situation. The way in which students think about situations, along with their beliefs, feelings and expectations, influences what and how students learn. Instead of being passively influenced by environmental events, students actively choose, practise and make many other responses as they pursue their goals. Teaching methods that emphasise relating new knowledge to the student's existing knowledge foster meaningful learning, and concept-mapping is one of the methods that meet this ideal.

\section{Epistemological foundation}

Epistemology is a branch of philosophy that deals with the nature of knowledge and new knowledge creation (Novak \& Canas 2006:7). Psychologists, philosophers and epistemologists argue that new knowledge creation is a constructive cognitive process involving both our knowledge and our emotions, or the drive to create new meanings and new ways to represent these meanings. Tikhomirov (1988:264) states that cognition is the activity of knowing, the acquisition, organisation and use of knowledge, which is driven by motivation and emotion. According to Paul (1993:465), emotion is a feeling aroused to the point of awareness, often a strong feeling or state of excitement. Negative emotions can hamper learning, as they encourage negativity, leading to the division of students in a group. Students who are able to manage their emotions are able to notice and make decisions about other students' moods, temperaments and intentions, and therefore interact with other students in a socially acceptable manner. Such students tend to have skills such as empathy, respect, flexibility and unconditional acceptance of others (Cooper \& Sawart 2000:324). Paul (1993:465) urges critical thinkers to monitor and manage their emotions and use their passions to reason themselves into feelings appropriate to the situation. Students should attempt to develop rational feelings and emotions in their group interaction, follow the arguments and decide things in terms of where they lead, as other students may have a point of view that is worth considering. Paul (1993:484) states that a student who fulfils the aforementioned is 'what we call a reasonable man'.

The creation of new knowledge cannot take place in a passive manner; it requires active engagement and participation and genuine commitment to the event. Vygotsky (1978:39) states that knowledge, ideas, attitudes and values are shaped mainly through our interaction with, and as a result of, stimulation from the environment. Vygotsky argues that all higher mental functions have their origins in social interactions. Educators should place students where they have to reach out to understand and stretch into areas beyond comfortable concepts. Students should be exposed to environments that will encourage them to discover new knowledge (Gagne 1977:163).

Constructivism is particularly congruent with the notion of self-directed learning and puts emphasis on active enquiry, independence and individuality in constructing meaning. According to Vygotsky (1978:124) and Peters (2000:166, 172), new knowledge is built on the existing knowledge that students bring to the learning situation. Learning is an active process in which the educator, as facilitator, is responsible for creating an enabling environment conducive to the construction of the students' own knowledge and skills through interaction. The methods of teaching selected must foster in students the ability to think critically and creatively in order to make meaningful sense of the learning situation (Mouton 1996:118).

Encouraging students to use concept-mapping as a learning method to explore and gain better understanding of a topic (for example, asthma) is to help them engage in a critical and creative thinking process and this can be challenging to students who come from a didactic environment that encourages rote learning. Rote learning encourages passivity, with no emotional engagement in the learning event, and therefore it cannot underpin creative and critical thinking in students. Educators are urged to create conducive environments to facilitate the creation of new knowledge to improve teaching methods that foster critical and analytical thinking in students (Ramsden 1992:86).

\section{Critical thinking}

A Delphi study was conducted by the American Philosophical Association (APA) from February 1988 to November 1989, 
under the leadership of Peter A. Facione. The purpose of the study was to critically analyse the concept of critical thinking. An interactive panel of 62 experts in critical thinking took part in the six rounds of the Delphi project. Fifty-two per cent of the participants were involved in Philosophy, 22\% in Education, $20 \%$ in the Social Sciences and 6\% in Physical Science. The panel identified six cognitive thinking skills (interpretation, analysis, evaluation, inference, explanation and self-regulation) and their related sub-skills, which are shown in Table 1. The affective dispositions that supports the cognitive skills were identified as inquisitiveness, analyticity, open-mindedness, systematic analysis, self-confidence and truth seeking thoughts (Facione 1990:6, 13; Proferto-McGrath 2003:571). In its fifth recommendation, the panel urged that the critical thinking framework should be used by educators to develop didactic activities such as a curriculum and evaluation instruments and to improve teaching and assessment methods (Facione 1990:13). The critical thinking framework is applied in this paper to improve the use of concept-mapping as a teaching method to facilitate critical thinking by students in nursing education.

The Delphi study by the American Philosophical Association (APA) defined critical thinking as a purposeful, self-regulatory judgment that results in the analysis, interpretation, inference, evaluation and explanation of the evidential, conceptual, methodological, criteriological or contextual considerations upon which that judgment is based. It is essentially a tool of inquiry (Facione 1990:2). The results of the Delphi study indicated that the characteristics of an ideal critical thinker are: habitually inquisitive, well-informed, trustful of reason, open-minded, flexible, fair-minded in evaluation, honest in facing personal biases, prudent in making judgments, willing to reconsider, clear about issues, orderly in complex matters, diligent in seeking relevant information, reasonable in the selection of criteria, focused in inquiry and persistent in seeking results that are as precise as the subject and the circumstances of inquiry permit (Facione 1990:2).

These characteristics play an important role when using concept-mapping to facilitate critical thinking by students. Critical thinking cannot be facilitated in a vacuum or in a robotic manner, focusing only on mass production, assembly-line, task-orientated methods (Karola 1995:36). Likewise, facilitating critical thinking through concept-mapping requires a domain context or theme with which the students should engage collaboratively. The theoretical framework for critical thinking in accordance with the APA Delphi study is represented in Table 1.

\section{DISCUSSION}

The cognitive thinking skills reflected in Table 1 do not necessarily suggest a linear form of reasoning. The thinking

TABLE 1

Core cognitive critical thinking skills, their sub-skills and the affective dispositions (Facione 1990:6, 13 \& Proferto-McGrath 2003:571) in relation to the educational process for concept-mapping as a teaching method

\begin{tabular}{|c|c|c|}
\hline $\begin{array}{l}\text { Core cognitive critical } \\
\text { thinking skills / Educational } \\
\text { process and concept } \\
\text { mapping }\end{array}$ & Related Sub-skills & Affective Disposition \\
\hline $\begin{array}{l}\text { 1. Assessment } \\
\text { (Identification of concepts) }\end{array}$ & $\begin{array}{l}\text { Examining ideas } \\
\text { Identifying arguments }\end{array}$ & $\begin{array}{l}\text { Inquisitiveness } \\
\text { Analyticity }\end{array}$ \\
\hline $\begin{array}{l}\text { 2. Planning/implementation } \\
\text { of the interactive constructing } \\
\text { process of learning activities } \\
\text { (analysis, interpretation } \\
\text { inference making, } \\
\text { explanation) }\end{array}$ & $\begin{array}{l}\text { Examining ideas } \\
\text { Analysing arguments } \\
\text { Categorisation } \\
\text { Decoding significance } \\
\text { Clarifying meaning } \\
\text { Justifying procedures }\end{array}$ & $\begin{array}{l}\text { Open-mindedness } \\
\text { Systematic } \\
\text { Self-confidence } \\
\text { Truth seeking }\end{array}$ \\
\hline $\begin{array}{l}\text { 3. Evaluation and feedback } \\
\text { (self-regulation, self- } \\
\text { monitoring, self-correction) }\end{array}$ & $\begin{array}{l}\text { Querying evidence } \\
\text { Conjecturing alternatives } \\
\text { Drawing conclusions } \\
\text { Stating results } \\
\text { Presenting arguments } \\
\text { Assessing claims } \\
\text { Assessing arguments }\end{array}$ & Cognitive maturity \\
\hline
\end{tabular}

skills are employed interactively and interchangeably in the critical and reflective reasoning process of making judgments on what to believe or do. Simpson and Courtney (2002:93) argue that, in thinking critically, a person not only tries to determine judiciously what to do or what to believe, but is also able to apply the core critical thinking skills to the problem at hand. In other words, one may analyse one's own inferences, explain one's own interpretation or evaluate one's own analysis. In practice, a nurse experienced in critical thinking will intuitively use all the core cognitive thinking skills simultaneously to provide specific emergency care in any clinical situation.

The discussion of the implementation of concept-mapping as a teaching method to facilitate critical thinking will take the form of the educational process (assessment, planning, implementation, evaluation and feedback) as determined by educational and cognitive psychologists (see below). In this discussion, conceptmapping steps two and three (planning and implementation) and steps four and five (evaluation and feedback) are combined.

\section{Assessment}

Educational and cognitive psychologists advocate the following aspects of the educational process when explaining how teaching and learning should take place (Bruner 1966; Gagne 1971; Knowles 1980; Rogers 1983; Vygotsky 1963). The first step is the assessment of background knowledge to determine the pre-existing concepts already known by the student. The process starts with the awareness of the situation. This step forms the basis of concept-mapping as a teaching method to facilitate critical thinking, because without the existence of some knowledge, no reflective or critical thinking will take place (Dewey 1933:99).

Several fundamental critical and reflective questions (Brookfield 1987:93) are asked in this step. Different questions require different modes of thinking (Paul 1993:336). The following questions may be asked regarding concept-mapping: what is the area, domain, field or discipline in which concept-mapping is to be used? Who are the participants and at what level of training are they? What background knowledge do they have in the specific subject? What other interdisciplinary knowledge or concepts do they possess in their cognitive structure that will help them to understand the selected topic? What is the focus area, theme or topic that is to be dealt with using concept-mapping? What supportive tools are needed to enable the construction process through concept-mapping (cards, colour pens, markers, rulers or extra paper)? Have the students identified the shape or format of the template? Do they need to use computer graphics? Have the students identified the members of their small working group? Have they identified the time and space needed for collaborative work to be engaged in? Have they identified the key concepts closely and distantly related to the domain as much as possible? How can concept-mapping as a teaching method be implemented differently? (Chabeli 2001:236, 237). The assessment step will end with a checklist of things to be assessed and to be identified by the students.

\section{Planning and implementation}

The interactive constructing process is a dynamic, mutual, collaborative exchange of ideas, thoughts and feelings between the student and the learning environment, and between the students themselves, in the quest to make meaning by constructing new knowledge and skills through interaction (Chabeli 2001:350). In their planning and implementation of a teaching method, nurse educators should be aware that students arrive at meaning by actively selecting and accumulatively constructing their own knowledge through interaction, rather than by receiving and storing knowledge. The student brings an accumulated baggage of knowledge, skills, attitudes and values to a particular teaching and learning situation, and these form an important framework that envelopes the immediate 
learning situation (Gravett 2001:19). This step requires the use of critical, creative, reflective and conceptualisation skills, which are regarded as higher thinking skills (Beyer 1988:53; Chabeli 2001:99)

Clarke, James and Kelly (1996:176) maintain that the interactive constructing process can be facilitated through teaching methods that encourage dialogue and an interactive, collaborative discussion among students. During this process there should be critical analysis that reviews and links the previous knowledge with the new knowledge for learning to take place (Scanlan \& Chernomas 1997:1139-1140). This is a data-gathering step in which students should demonstrate critical thinking dispositions such as flexibility, willingness, open-mindedness, an inquiring mind and analyticity in gathering data about the phenomenon (Facione 1990:13). The cognitive skills of analysis, interpretation and inference play an integral part in this step.

Analysing is taking apart, disassembling and deconstructing in order to perceive or establish a pattern or relationship(s) (Beyer 1988:19). It is a process of breaking up a whole into its parts to examine the details so as to determine the nature of a phenomenon (Paul 1993:458). During this step, students are expected to explore, examine and analyse the identified concepts, statements, main ideas, thoughts, clues or patterns of significance in detail to have clarity in the process. The students should engage in brainstorming ideas and thoughts to generate large sets of concepts and statements that address the focus area without judging or editing the information (Plotnick 1997:1). Students should try to understand the flow of ideas. At this stage, students should not worry about redundancy, or the relative importance of the information or the relationships. This is the step in which students would generate the largest possible list of concepts and statements.

Interpretation is a process in which one gives one's own conception of a phenomenon in order to place it in the context of one's own experience, perspective, point of view or philosophy (Paul 1993:473). The best interpretation takes the most evidence and justification into account. Interpretation is weighing evidence and deciding whether generalisations or conclusions based on the data collected are warranted (Watson \& Glaser 1980:2). Having analysed and generated numerous facts, thoughts, ideas, concepts and statements, the students should engage in collaborative dialogue to interpret the information meaningfully. Dialogue, like critical thinking, engages students actively in their learning. A successful dialogue involves a willing partnership and is marked by a sharing and empathetic attitude, cooperation, mutual respect and trust, especially in the face of likely disagreements, confusion and misunderstandings (Gravett 2001:47).

Dialogue is exploratory and interrogatory for the purpose of breaking through to new insights and different perspectives and allowing for conceptual change to take place (Chabeli 2006:83). It encourages critical thinking and a deep approach to learning as students engage in a search for meaning and active understanding through active participation in exploratory discussion, debates and brainstorming during concept-mapping. The interpretation requires students to be open and fair-minded. During this step of concept-mapping, students should make interdisciplinary connections by using other related knowledge from subjects like anatomy, physiology, microbiology, pharmacology, psychology, sociology, chemistry and physics to enhance the process of data interpretation. Interpretation involves the process of categorisation, decoding significance and clarifying meaning (Facione 1990:6, 7).

Inference is defined as the movement of thoughts that proceed from something given, a cue or data, to a conclusion as to what the data mean or signify (Bandman \& Bandman 1988:120). Beyer (1988:112) believes that to infer is to draw conclusions, make predictions, pose hypotheses and test and explain hypotheses. To make an inference, according to Paul (1993:115), is to think as follows: because this is so, that also is so or probably so. Students make inferences through the concepts and statements that they bring to the learning situation. Inference brings together all the various elements needed to query the evidence collected, to draw reasonable conclusions and to form conjectures (Facione 1990:6; Proferto-McGrath 2003:571). The students should generate more information and make accurate inferences in the presence of more evidential information. Through dialogue students should construct maps from identified concepts so as to be able to formulate meaning which will assist them to remember information when it is needed.

Formulation is a 'doing' aspect of concept-mapping in which the identified concepts and statements are formulated, structured and represented in an organised and meaningful manner. The thinking skills of synthesis and organisation of identified concepts play an integral role during the formulation process of concept-mapping. The process of synthesis uses creativity and imagination thinking skills to develop new concepts and to view issues with a different perspective (Atkins \& Murphy 1993:1190). What is created is always new, unique and goal-directed. The success of the student's ability to synthesise depends on the student's organisational ability in forming patterns or clusters of concepts and statements through organised reasoning to bring about conceptual change (Bybee \& Sund 1982:194). The students should be actively involved in sorting the concepts into piles of similar ones, using card systems or categorising them directly on a computer by dragging the concepts and statements into piles that they create. Piles are named with a short descriptive label. Each statement is rated on some scale of 1-5 according to its importance, where 1 means the statement is unimportant and 5 means that it is extremely important (Trochim 2006:2, 3; Novak 2007:3).

Clusters of activities are organised into logical groups of activities, for example a learning area focusing on 'asthma'. The concept 'asthma' can be placed strategically in the centre, or at any point from where a cluster of causes can be constructed - allergens, respiratory tract infections, cold air, exercises, drugs, chemicals, emotional upset and pollutants, for example. The treatment of asthma can be clustered under the headings pharmacological and non-pharmacological. Pharmacological can be clustered into homeopathic herbs, traditional medicines and Western medicine. Clustering may go on and on for better understanding.

Students are encouraged to engage in collaborative dialogue, connecting new information to existing knowledge and integrating interdisciplinary knowledge, to arrive at meaningful concept-mapping. The students should be free to use their creativity and imagination, as demonstrated by a deliberate choice of style, format, using different colour-coding and shapes, arrows to join ideas from different branches or drawing circles around related ideas to enhance meaning and understanding. All of this leads to new insights and conceptual change. The students should experience the 'A-ha' feeling, and become excited about their sudden understanding of a complex phenomenon such as asthma. There should be no coercion from the nurse educator in the process of refining the map.

At the end of the formulation of the concept map, the students should demonstrate critical thinking dispositions, such as selfconfidence in providing explanations of the reasoning process behind the formulation. According to Facione (1990:10), explanation means to state the results of one's reasoning, to justify that reasoning in terms of the evidential, conceptual, methodological, criteriological and contextual considerations upon which one's results were based and to present one's reasoning in the form of cogent arguments. During the explanation, the students justify and present arguments based on their interpretations, analysis, evaluations or inferences, so that they can accurately record, evaluate, describe or justify those 
processes to themselves or to others, or so that they can remedy perceived deficiencies in the general way they execute those processes. The nurse educator should create an environment of freedom, respect and trust, encouragement and support, and of motivation and guidance towards the facilitation of critical thinking by students through concept-mapping.

\section{Evaluation and feedback}

The concept map formulated in this way can now be used as a visual framework for learning the selected learning area, for example asthma. It can also be used as the basis for developing measures of understanding and displaying the results of the thinking process. The concept map can be given a title and can be placed on PowerPoint so that other students can view it and take the discussion further.

It is important to recognise that a concept-map is never finished (Novak 2007:3). It is always necessary to evaluate and revise the map. Good concept maps usually undergo many revisions concerning the positioning of concepts and statements in ways that lend clarity, and ordering or re-ordering the related crosslinks. Evaluation is the process of judging or determining the worth, accuracy, completeness or quality of a phenomenon (Beyer 1988:334). Evaluation has a logical component and should be carefully distinguished from mere subjective performance. The elements of its logic may be put in the form of questions, which may be asked whenever an evaluation is to be carried out (Paul 1993:466)

Students should be encouraged to revise their concept maps. According to Dewey (1933:9), the development of reflective questions and an inquiring mind are integral to the facilitation of critical thinking. Questions such as the following are usually helpful:

- is the concept map clear?

- is it logically constructed?

- $\quad$ is the map accurate, attractive, thorough and organised?

- does the map demonstrate creativity and imagination?

- how do the concept and interlinking statements fit together?

- could it have been constructed differently?

- what would have been the alternative approach to facilitating critical thinking through concept-mapping?

- does it make sense, is it meaningful? Why or why not?

- is there anything missing, unclear, or problematic about the map?

- how does it fit with the student's experience?

The more closely one looks at the map and the material used, the more questions will come to the fore and the more selfmonitoring will occur to check the good reasoning ability of students or where things went wrong. If something does not make sense, or seems unresolved, the students should try to state explicitly why - in what way is there a problem? This may be difficult to do, but it is a worthwhile exercise because it will make it easier for students to find answers (Counseling Services 2003:6). Self-regulation occurs when one self-consciously monitors one's cognitive activities, the elements used in those activities, and the results deduced, particularly by applying skills in analysis and evaluation to one's own inferential judgment with a view to questioning, confirming, verifying or correcting either one's reasoning or one's results (Facione 1990:10). This step demonstrates the critical thinking disposition of truth seeking and intellectual maturity.

Evaluation should be ongoing throughout the activities of concept-mapping. Critical thinking is an integral part of the evaluation process. It is used to assess the credibility of concepts and statements or other representations made on the map. It assesses the claims and the contextual relevance of the information gathered to formulate the map. Feedback should be realistic, specific, timely, descriptive and positive. It should be sensitive to the goals of the learners and be consciously nonjudgmental. Feedback should be propedious and allow students to grow in their learning (Chabeli 2005:28, 29).

\section{RECOMMENDATIONS}

Nursing in general and clinical nursing education in particular are complex human activities that present real and unique problems, both structured and unstructured (King \& Kitchener 1997:33). Facilitating critical and reflective thinking in nursing students will remain a challenge for nurse educators. It is therefore recommended that nurse educators focus on formulating hypotheses and engaging in further research on the validity of teaching methods that facilitate reflective and critical thinking. The interactive, dialogic and collaborative approaches to learning are at the forefront of the facilitation of reflective and critical thinking to promote deeper understanding, thereby enriching the general psychological theory of thinking (Tikhomirov 1988:269).

Concept maps are valuable tools with which to harness the power of the learners' vision to understand complex information at a glance. Concept-mapping is a teaching method to facilitate creative, reflective and critical thinking. It is recommended that nurse educators use concept-mapping to facilitate critical thinking and encourage a deep approach to learning. Educators are urged to use concept-mapping as a method of individual or group assessment and evaluation to assess the learners' conceptual understanding and handling of complex information. Educators can use concept-mapping to plan and revise curricula. They should encourage learners to use concept-mapping to make summaries of large chunks of information.

Concept-mapping can also be used to plan research activities and to plan patient care. It can be a valuable method to teach clinical nursing education - for example, nursing care of a patient on peritoneal or haemodialysis.

\section{CONCLUSION}

Critical thinking has become a national issue in the education arena. Educators might be successful in teaching the basics, but are perhaps not always sure that their students will be able to analyse and evaluate what they are taught. The question that arises is:

- will the students go beyond the book knowledge or the information they were given to generate new ideas?

- will they be able to meaningfully interpret the information given, or to make meaningful connections with the existing framework?

- will they be able to make accurate inferences and explanations, as required?

- do the students demonstrate inquisitiveness, willingness, open-mindedness, flexibility, self-confidence and cognitive maturity during the active acquisition of new knowledge, skills, attitudes and values?

This is a huge challenge to educators in general and to nurse educators in particular, as the nursing profession requires nurses who have well-developed critical and creative thinking skills with which to organise, reorganise, conceptualise or reconceptualise problems and come up with feasible, rational solutions or astute clinical judgments (Facione 1990:6, 13; Woolfolk 1990:276). Nurses need critical thinking skills to perform their daily functions in practice.

In this paper, the author has tried to discuss concept-mapping as a teaching method to facilitate critical thinking by students by exploring the theoretical framework and epistemological foundation of concept-mapping. The theoretical framework of critical thinking has provided the framework within which concept-mapping can be implemented in accordance with 
the educational process format. Further research should be conducted to implement concept-mapping as a teaching method to facilitate critical thinking by student nurses.

\section{REFERENCES}

Akinsanya, C. \& Williams, C., 2004, 'Concept-mapping for meaningful learning', Nurse Education Today 24, 41-46.

All, A. \& Havens, R.L., 1997, 'Cognitive/concept-mapping: A teaching strategy for nursing', Journal of Advanced Nursing $25,1210-1219$.

Atkins, S. \& Murphy, K., 1993, 'Reflections: A review of the literature', Journal of Advanced Nursing 18, 1188-1192.

Ausubel, D.P., 1963, The psychology of meaningful verbal learning, Grune and Stratton, New York.

Ausubel, D.P., Novak, J.D. \& Hanesian, H., 1978, Educational psychology: A cognitive view, 2nd edn., Holt, Rinehart \& Winston, New York.

Bandman, E.L. \& Bandman, B., 1988, Critical thinking in nursing, Appleton and Lange, New York.

Beyer, B.K., 1988, Developing a thinking skills program, Allyn and Bacon, London.

Brookfield, S., 1987, Developing critical thinkers, Open University, Milton Keynes.

Bruner, J.S., 1966, Towards a theory of instructions, Norton, New York.

Bybee, R.W. \& Sund, R.B., 1982, Piaget for education, Charles E. Merrill, London.

Chabeli, M.M., 2001, 'A model to facilitate reflective thinking in clinical nursing education', DCur thesis, Department of Nursing, University of Johannesburg.

Chabeli, M.M., 2005, Alternative assessment and evaluation methods in clinical nursing education, Monograph 4, Nursing Department, University of Johannesburg.

Chabeli, M.M., 2006, 'Higher order thinking skills competencies required by outcomes-based education from learners', Curationis 29(3), 78-86.

Clarke, B., James, C. \& Kelly, J., 1996, 'Reflective practice: Reviewing the issue and refocusing the debate', International Journal of Nursing Studies 33, 171-180.

Cooper, R.K. \& Sawart, A., 2000, Executive EQ: Emotional intelligence in business, Texere Publishing, New York.

Counselling Services, 2003, Concept-mapping, University of Victoria.

Dewey, J., 1933, How we think. A restatement of the relation of reflective thinking to the educative process, Lexington, Massachusetts, Health and Company.

Facione, P.A., 1990, 'Critical thinking: A statement of expert consensus for purpose of educational assessment and instruction'. Executive summary, The Delphi Report, California Academic Press, Millibrae.

Fraser, W.J., Loubser, W.J. \& Van Rooy, M.P., 1993, Didactics for the undergraduate students, Butterworth Publishers, Durban.

Gagne, R.M., 1971, The conditions of learning, Holt-Rinehart \& Winston, London.

Gagne, R.M., 1977, The conditions of learning, Holt-Rinehart \& Winston, New York

Gravett, S., 2001, Adult learning: Designing and implementing learning events - a dialogic approach, Van Schaik Publishers, Pretoria.
Karola, M., 1995, 'Nursing process', Australian Nursing Journal 2(9), 36-39.

King, P.M. \& Kitchener, K.S., 1997, Developing reflective judgment. Understanding and promoting intellectual growth and critical thinking in adolescents and adults, Jossey-Bass Publishers, San Francisco.

Knowles, M.S., 1980, The modern practice of adult education. From pedagogy to andragogy, Cambridge Adult Education/Prentice Hall Regents, New York/Englewood Cliffs.

Mellish, J.M., Brink, H.I.L. \& Paton, F., 1998, Teaching and learning the practice of nursing, Heinemann Publishers, Johannesburg.

Mouton, J., 1996, Understanding social research, JL van Schaik Publishers, Pretoria.

Novak, J.D., 2007, 'Concept maps. What the heck is this?', viewed 12 September 2007, from http://www.msu.edu/ luckie/ ctools/

Novak, J.D. \& Canas, A.J., 2006, 'The theory underlying concept maps and how to construct them. Florida Institute for Human and Machine Cognition Pensacola FI, 32502', viewed 20 September 2007, from http:// www.ihmc.us

Paul, R., 1993, Critical thinking: What every person needs to survive in a rapidly changing world, Foundation for Critical Thinking, Santa Rosa.

Peters, M., 2000, 'Does constructivist epistemology have a place in nursing education?', Journal of Nurse Education 39, 166-172.

Plotnick, E., 1997, Concept-mapping: Concept-mapping A graphical system for understanding the relationship between concepts, Eric Clearinghouse on Information and Technology, Syracuse.

Proferto-McGrath, J., 2003, 'The relationship of critical thinking skills and the critical thinking dispositions of baccalaureate nursing students', Journal of Advanced Nursing 43, 569-577.

Quinn, F.M., 1980, The principle and practice of nurse education, Croon Helm, London.

Ramsden, P., 1992, Learning to teach in higher education, Routledge, London.

Rensburg, I., 2007, 'Ivory towers, slot machines or pathfinders. University and the case for executive leadership' Vice Chancellor's Inaugural address, University of Johannesburg.

Rogers, C.R., 1983, Freedom to learn for the 80's, Charles E. Merrill, Columbus.

Scanlan, J.M. \& Chernomas, W.M., 1997, 'Developing the reflective teacher', Journal of Advanced Nursing 25, 1138-1143.

Simpson, E. \& Courtney, M., 2002, 'Critical thinking in nursing education: Literature review', International Journal of Nursing Practice 8, 89-98.

Thompson, S. \& Jolley, M., 1997, Nurse teachers as researchers. A reflective approach, Arnold.

Tikhomirov, O., 1988, The psychology of thinking, Progress Publishers, Moscow.

Trochim, W.M.K., 2006, 'Concept-mapping', viewed 02 September 2007, from http://www.socialresearchmethods.net/kb/conmap. php

Van der Host, H. \& McDonald, R., 1997, Outcomes-based education. A teacher's manual, Kagiso, Pretoria.

Vygotsky, L.S., 1963, Learning and mental development at school age, MIT Press, Cambridge

Vygotsky, L.S., 1978, Mind in society, the development of higher psychological processes, Harvard University Press, London.

Watson, G. \& Glaser, E.M., 1980, Critical thinking appraisal manual, Psychological Corporation - Harcourt Brace Jovanovic, New York.

Woolfolk, A.E., 1990, Educational psychology, Prentice-Hall, New Jersey. 